\title{
Relationship of Characteristics, Lifestyle and Exposure of Carbon Monoxide with Blood Pressure of Motorcycle Repair Shop Mechanics at Medan City in 2020
}

\author{
Kanaya Yori Damanik ${ }^{1}$, Nurmaini ${ }^{2}$, Irnawati Marsaulina ${ }^{3}$ \\ ${ }^{1,2,3}$ Universitas Sumatera Utara, Indonesia \\ Corresponding Author: Kanaya Yori Damanik
}

\begin{abstract}
High blood pressure is a condition where the systolic blood pressure is $>140 \mathrm{mmHg}$ and diastolic $>90 \mathrm{mmHg}$. Hypertension is one of the leading causes of death in the world. The factors that cause hypertension are genetics, age, obesity, lifestyle, stress, and food consumption patterns. Continuous exposure to carbon monoxide gas at high concentrations can also cause an increase in blood pressure. This study aims to analyze the relationship of characteristics, lifestyle, and exposure of carbon monoxide with blood pressure of motorcycle repair shop mechanics at Medan City. This study is an observational study using a crosssectional design. This research was conducted at 12 workshops in 6 sub-districts in Medan City. The sample in this study amounted to 70 mechanics. Carbon monoxide exposure data were calculated using the intake formula in the ARKL study. Mechanical blood pressure data were obtained by direct measurement twice with an interval of five minutes using a sphygmomanometer. Data analysis was done using bivariate test. The results showed that 54.3 percent of mechanics had high blood pressure and there was one workshop that had a $\mathrm{CO}$ concentration in the air that exceeded the quality standard value, namely $31,329.2 \mu \mathrm{g} / \mathrm{Nm} 3$. There was a significant relationship between a history of hypertension $(\mathrm{p}=0.005)$, smoking habits $(\mathrm{p}=0.001)$, physical activity $(\mathrm{p}=0.006)$, and sodium intake $(\mathrm{p}=0.015)$ with blood pressure. There was no significant relationship between exposure of carbon monoxide and systolic pressure $(\mathrm{p}=0.067)$ and diastolic $(\mathrm{p}=0.606)$. Mechanics should be able to change and control
\end{abstract}

risky lifestyles by increasing physical activity, controlling cigarette consumption, reducing sodium consumption, routinely going to health services and taking hypertension drugs for mechanics who have high blood pressure.

Keywords: History of Hypertension, Smoking Habits, Physical Activity, Sodium Intake, Carbon Monoxide, Systolic, Diastolic, Blood Pressure.

\section{INTRODUCTION}

A person is considered to have high blood pressure if normal blood pressure remains above 140 per $90 \mathrm{mmHg}$, it is said to have high blood if the systolic pressure is $>140 \mathrm{mmHg}$ and the diastolic is $>90 \mathrm{mmHg}$ (Watson, 2002).

Blood pressure is a number of compressive forces used by blood on the arteries of the blood vessels when the heart pumps blood throughout the body (Guyton and Hall, 2016). Blood pressure is measured in millimeters of mercury $(\mathrm{mmHg})$. The measurements used are systolic pressure and diastolic pressure. Blood pressure is divided into four categories, namely normal if the systolic pressure is $<120 \mathrm{mmHg}$ or diastolic $<90 \mathrm{mmHg}$, prehypertension if the systolic is $120-139 \mathrm{mmHg}$ or diastolic $80-89 \mathrm{mmHg}$, first-level hypertension if the systolic pressure is $140-159 \mathrm{mmHg}$ or diastolic 90 $99 \mathrm{mmHg}$, as well as second-degree hypertension if the systolic pressure is $\geq 160$ $\mathrm{mmHg}$ or diastolic $\geq 100 \mathrm{mmHg}$. 
According to the Ministry of Health of the Republic of Indonesia, blood pressure is high (hypertension) if the systolic blood pressure is more than $140 \mathrm{mmHg}$ and diastolic blood pressure is more than 90 $\mathrm{mmHg}$. Data from WHO in 2015, there are about 1.13 billion people in the world who have hypertension. This means that out of three people, one of them is diagnosed with hypertension. Each year, people with hypertension will continue to grow. In 2025 it is estimated that there will be 1.5 billion people who have high blood pressure and 10.44 million people die from hypertension and complications each year (Dinas Kesehatan Provinsi Sumatera Utara, 2019).

Death data from the Institute for Health Metrics and Evaluation (IHME) in 2017 shows that of the 53.3 million deaths in the world, 33.1 percent are due to cardiovascular disease, 16.7 percent due to cancer, 6 percent due to diabetes mellitus and endocrine disorders and under 4,8 percent due to respiratory tract infections. In Indonesia, the biggest cause of death in 2016 was cardiovascular disease, accounting for 36.9 percent of the 1.5 million deaths.

Riskesdas 2018 shows the fact that there are more than 63 million Indonesians who have high blood pressure (hypertension). The highest prevalence of hypertension occurred in the age group 5564 years $(55.2 \%)$, group $45-54$ years $(45.4 \%)$, and age group 31-44 years $(31.6 \%)$. The death rate in Indonesia due to hypertension is 427,218 .

Data obtained from the North Sumatra Provincial Health Office in 2015, recorded that hypertension sufferers in North Sumatra in January-October 2015 reached 151,939 people. The highest number of sufferers was women with a total of 87774 . The age of most patients seen in that data was also those over 55 years old with a total of 85254 , followed by ages 45 to 55 years (Dinas Kesehatan Provinsi Sumatera Utara, 2015). In the city of Medan in 2017 , there were 53,706 people with hypertension (Dinas Kesehatan Provinsi Sumatera Utara, 2015).

High blood pressure is currently a serious problem not only in Indonesia but in the world because high blood pressure that occurs continuously is one of the factors causing other diseases such as heart disease, kidney failure, diabetes, and stroke. Most people diagnosed with hypertension did not regularly take medication (32.3\%). This shows that most hypertension sufferers do not know that they have high blood pressure so they do not get treatment (Dinas Kesehatan Provinsi Sumatera Utara, 2018).

High blood pressure (hypertension is one of the silent killer diseases. Symptoms of people with high blood pressure can vary from person to person and the symptoms are almost similar to other diseases. Symptoms of high blood pressure that can be felt are headaches or pain in the nape of the head, ears) frequent ringing, blurred vision, vertigo, bleeding from the nose (nosebleeds), racing heart racing and easily feeling tired (Dinas Kesehatan Provinsi Sumatera Utara, 2014).

Hypertension is one of the leading causes of death in the world. The factors that cause hypertension are genetics, age, obesity, lifestyle, stress, and food consumption patterns. Continuous exposure to carbon monoxide gas at high concentrations can also cause an increase in blood pressure.

The risk factors for hypertension are divided into two, namely factors that cannot be controlled and factors that can be controlled. The factors that can be controlled are age, gender, and genetics. High blood pressure occurs mostly in young adult men (Nuranto, 2014). With age, blood pressure also increases slowly but will increase in height when you enter the age of 40 (Guyton and Hall, 2016). The research conducted by Sarumaha (2018) shows that genetic risk factors have a greater influence on the incidence of hypertension than other factors. About 70-80 percent of people with essential hypertension have a family history of hypertension. If a history of hypertension 
is obtained in both parents, the suspicion of essential hypertension is greater.

In the air, 0.032 percent of $\mathrm{CO}$ is produced by incomplete combustion. Motorized vehicles that run on gasoline produce about 1 percent of carbon monoxide when walking and about 7 percent when they are not walking. Meanwhile, carbon monoxide gas produced by diesel engines is 0.2 percent when it is running and 4 percent when it is not running (Sarudji, 2010).

Places that allow pollution due to motor vehicle exhaust gases are motorcycle workshops. Workshops have a higher risk of experiencing motor vehicle emission pollution than other places such as roads because dynamic pollutants are conditioned to become static pollutants, while many workshops do not equip an adequate system to overcome this problem (Soedarmo, 2008). An enclosed space without an air exchange system will cause emissions to accumulate and increase in concentration. This is very dangerous for workshop mechanics who are in direct contact with contaminants in the workshop every day.

Based on the preliminary survey conducted by the researchers, by interviewing 15 workshop workers, there were 12 people who had health complaints including dizziness, sore neck, fatigue, blurred vision, ringing in the ears, and so on. Many mechanics feel health complaints with symptoms of hypertension but most mechanics do not know their blood pressure status because they rarely go to health care providers and some even never check their blood pressure. The motorcycle repair shop in Medan City is crowded with customers and employs many workers. The average worker works 8 hours per day or more. The mechanic does not use any PPE such as masks or gloves while working. Without a mask, the exhaust gases from motorized vehicles will be inhaled directly by workers while working.

This study aims to analyze the relationship of characteristics, lifestyle, and exposure of carbon monoxide with blood pressure of motorcycle repair shop mechanics at Medan City.

\section{RESEARCH METHODS}

The type of research used is quantitative observational research with cross sectional design in which data collection is carried out at one time or the same period in measuring the independent and dependent variables.

This research was conducted at 12 workshops in 6 sub-districts in Medan City. The sample in this study amounted to 70 mechanics.

Carbon monoxide exposure data were calculated using the intake formula in the ARKL study. Mechanical blood pressure data were obtained by direct measurement twice with an interval of five minutes using a sphygmomanometer.

Data analysis was done using bivariate test.

\section{RESULT \\ Carbon Monoxide Concentration}

The results showed that 54.3 percent of mechanics had high blood pressure and there was one workshop that had a $\mathrm{CO}$ concentration in the air that exceeded the quality standard value, namely 31,329.2 $\mu \mathrm{g} / \mathrm{Nm} 3$.

Carbon monoxide samples were taken for one hour at one point in each workshop. The concentration of carbon monoxide at 12 measurement points in 12 workshops ranged between 2,577.9 $\mu \mathrm{g} /$ $\mathrm{Nm} 3$ and $31,329.2 \mu \mathrm{g} / \mathrm{Nm} 3$ with an average concentration of $10,817.9 \mu \mathrm{g} / \mathrm{Nm} 3$.

The highest concentration of carbon monoxide gas was at Bengkel $\mathrm{E}$, measuring point five at $31,329.2 \mu \mathrm{g} / \mathrm{Nm} 3$. There are six mechanics who work in Workshop E and five of them have high blood pressure. Of the five people, one person has an excess body mass index, two people have a history of hypertension, two are heavy smokers, one person has a moderate drinking habit, which is spending 2-3 glasses per drinking alcohol, four people with moderate physical activity. mild, three people with excess sodium 
intake. Four of them are under 31 years old and one person is 32 years old.

Workshop $\mathrm{E}$ is a workshop that performs the most servicing activities. During one hour of air sampling, 15 motorbikes were repaired. Service activities carried out in this workshop also turn on and emit more smoke and noise. As a result, the concentration in this workshop was much higher than that of other workshops. In addition, because many visitors repair motorbikes, the workshops are crowded and on average, visitors smoke while waiting in line for their motorbikes. This also contributes to increasing the concentration of carbon monoxide in this workshop.

At the time of taking air samples, there were two workshops that did not allow the air sampler to be placed in the middle of the motorcycle repair area for fear of disturbing the mechanical space so that the air sampling tool was placed at the end of the repair area closer to the wall. The two workshops are Bengkel I and Bengkel K.

The carbon monoxide concentration in Bengkel I was 5,498.4 $\mu \mathrm{g} / \mathrm{Nm} 3$. There are 6 mechanics who work in the workshop and only two of them have high blood pressure. Both people had normal body mass index, had a history of hypertension, had light physical activity, had excessive sodium intake, and one person was a heavy smoker. Both have low carbon monoxide exposure (intake). At the time of the sampling at Workshop I, the number of vehicles repaired was 12 motorbikes.

The lowest carbon monoxide concentration was at Bengkel $\mathrm{K}$, which was 2,577.9 $\mu \mathrm{g} / \mathrm{Nm} 3$. There are six mechanics who work at the $\mathrm{K}$ Workshop and three of them have high blood pressure. Of the three people, all were heavy smokers with light physical activity, two people had excessive sodium intake and two people aged >31 years.

The temperature at the $\mathrm{K}$ Workshop at the time of the study was $31^{\circ} \mathrm{C}$ which is the highest temperature compared to other workshops, the humidity of 66.7 percent which is also the lowest compared to other workshops. At the time of sampling, there were not too many repaired motorbikes. There were 8 motorbikes that were repaired during one hour of sampling. Motorcycle repairs are carried out without starting the engine. After being repaired, the motorbike was brought by the mechanic to the road to run so that the vehicle smoke that accumulated in the workshop was not much.

\section{Carbon Monoxide Exposure}

Carbon monoxide exposure in this study ranged from $0.34 \mathrm{mg} / \mathrm{kg} /$ day to 3.62 $\mathrm{mg} / \mathrm{kg} /$ day. Exposure $0.34-0.80 \mathrm{mg} / \mathrm{kg} /$ day distributed to mechanics working in $\mathrm{G}, \mathrm{H}, \mathrm{I}$, $\mathrm{J}, \mathrm{K}, \mathrm{L}$ workshops. Of the 27 people who received exposure $0.34-0.80 \mathrm{mg} / \mathrm{kg} /$ day, 13 of them had hypertension. The highest exposure was 3.16-3.62 $\mathrm{mg} / \mathrm{kg} /$ day, distributed at Bengkel $\mathrm{E}$ and Bengkel $\mathrm{F}$, which were the two workshops with the highest carbon monoxide concentration. Of the 8 people who received exposure to $3.16-$ $3.62 \mathrm{mg} / \mathrm{kg} /$ day, 5 of them had hypertension. The size of the exposure depends on the amount of carbon monoxide concentration in the workshop air. The higher the $\mathrm{CO}$ concentration in the air, the greater the exposure received by the mechanic.

The difference in the amount of exposure received by the mechanic also depends on the weight of the mechanic. The heavier the mechanical body, the less exposure it receives. In theory, carbon monoxide exposure can affect blood pressure, but in this study the results showed that there was no relationship between carbon monoxide exposure and mechanical blood pressure. The average carbon monoxide intake received by mechanics with an excess body mass index was 1.71 $\mathrm{mg} / \mathrm{kg} /$ day. The average carbon monoxide intake received by mechanics with a normal body mass index was $1.22 \mathrm{mg} / \mathrm{kg} /$ day. It can be seen that there is no significant difference in exposure (intake) received by mechanics with excess and normal body mass index. 

blood pressure of motorcycle repair shop mechanics at Medan City in 2020.

The smallest carbon monoxide exposure was at Bengkel $\mathrm{K}$ because the carbon monoxide concentration in Bengkel $\mathrm{K}$ was also the smallest. The biggest carbon monoxide exposure was at Bengkel $\mathrm{E}$ because the carbon monoxide concentration in Bengkel $\mathrm{E}$ was also the biggest. Workshop $\mathrm{E}$ is the workshop that has the most mechanics with high blood pressure compared to other workshops. Five of the six workers have hypertension.

\section{Bivariate Test}

From the results of the bivariate test analysis, it can be seen that there is no significant relationship between mechanical body mass index and blood pressure $(\mathrm{p}=0.666, \mathrm{p}>0.005)$.

Table 1. Relationship between Mechanical Characteristics and Blood Pressure

\begin{tabular}{|c|c|c|c|c|c|c|c|}
\hline \multirow[t]{3}{*}{ Mechanical Characteristics } & \multicolumn{4}{|c|}{ Blood Pressure } & \multirow{2}{*}{\multicolumn{2}{|c|}{ Total }} & \multirow[t]{3}{*}{$\mathbf{p}$} \\
\hline & \multicolumn{2}{|c|}{ Normal } & \multicolumn{2}{|c|}{ High } & & & \\
\hline & $\mathbf{n}$ & $\%$ & n & $\%$ & $\mathbf{N}$ & $\%$ & \\
\hline Age & & & & & & & 0.711 \\
\hline$\leq 31$ Year & 24 & 47.1 & 27 & 52.9 & 51 & 100.0 & \\
\hline$>31$ Year & 8 & 42.1 & 11 & 57.9 & 19 & 100.0 & \\
\hline Years of Service & & & & & & & 0.557 \\
\hline$\leq 5$ Year & 18 & 42.9 & 24 & 57.1 & 42 & 100.0 & \\
\hline$>5$ Year & 14 & 50.0 & 14 & 50.0 & 28 & 100.0 & \\
\hline History of Hypertension & & & & & & & 0.005 \\
\hline Yes & 5 & 21.7 & 18 & 78.3 & 23 & 100.0 & \\
\hline No & 27 & 57.4 & 20 & 42.6 & 47 & 100.0 & \\
\hline Body Mass Index & & & & & & & 0.666 \\
\hline Normal & 25 & 47.2 & 28 & 52.8 & 53 & 100.0 & \\
\hline Excess & 7 & 41.2 & 10 & 58.8 & 17 & 100.0 & \\
\hline
\end{tabular}

In Table 2, you can see the results of the bivariate analysis between lifestyle and blood pressure. From the results of the chi square test between mechanical smoking habits and blood pressure, it is known that there is a significant relationship ( $p=0.001$, $\mathrm{p}<0.05$ ) where the percentage of heavy smokers who have hypertension is 89.5 percent.

The results of bivariate analysis on mechanical alcohol drinking habits with blood pressure showed insignificant results $(p=0.865, p>0.05)$ because the majority of mechanics with high blood pressure did not drink alcohol at 54.9 percent.
The majority of mechanics who have light physical activity have high blood pressure with a percentage of 62.5 percent. The results of the bivariate analysis between physical activity and blood pressure using the chi square test showed that there was a significant relationship between the two $(\mathrm{p}=0.006, \mathrm{p}<0.05)$.

From the analysis, mechanical daily sodium intake had a significant relationship with blood pressure $(\mathrm{p}=0.015, \mathrm{p}<0.05)$. Mechanics with excess daily sodium intake had high blood pressure as much as 69.7 percent

Table 2. The Relationship between Lifestyle and Blood Pressure

\begin{tabular}{|c|c|c|c|c|c|c|c|}
\hline \multirow[t]{3}{*}{ Lifestyle } & \multicolumn{4}{|c|}{ Blood Pressure } & \multirow{2}{*}{\multicolumn{2}{|c|}{ Total }} & \multirow[t]{3}{*}{$\mathbf{p}$} \\
\hline & \multicolumn{2}{|c|}{ Normal } & \multicolumn{2}{|c|}{ High } & & & \\
\hline & $\mathbf{n}$ & $\%$ & $n$ & $\%$ & $\mathbf{n}$ & $\%$ & \\
\hline Smoking & & & & & & & 0.001 \\
\hline Moderate & 30 & 58.8 & 21 & 41.2 & 51 & 100.0 & \\
\hline Weight & 2 & 10.5 & 17 & 89.5 & 19 & 100.0 & \\
\hline Habit of Drinking Alcohol & & & & & & & 0.865 \\
\hline No & 23 & 45.1 & 28 & 54.9 & 51 & 100.0 & \\
\hline Yes & 9 & 47.4 & 10 & 52.6 & 19 & 100.0 & \\
\hline Physical Activity & & & & & & & 0.006 \\
\hline Light & 21 & 37.5 & 35 & 62.5 & 56 & 100.0 & \\
\hline Weight & 11 & 78.6 & 3 & 21.4 & 14 & 100.0 & \\
\hline Asupan Natrium & & & & & & & 0.015 \\
\hline Enough & 22 & 59.5 & 15 & 40.5 & 37 & 100.0 & \\
\hline More & 10 & 30.3 & 23 & 69.7 & 33 & 100.0 & \\
\hline
\end{tabular}


Kanaya Yori Damanik et.al. Relationship of characteristics, lifestyle and exposure of carbon monoxide with blood pressure of motorcycle repair shop mechanics at Medan City in 2020.

The relationship between carbon monoxide exposure and blood pressure was calculated using the Spearman Correlation by first doing the Kolmogorov Smirnov normality test and the results showed that the data distribution was not normal so the Spearman correlation test was used.

Table 3. Relationship between CO Exposure and Systolic Blood Pressure

\begin{tabular}{|l|l|l|r|r|}
\hline \multicolumn{3}{|c|}{ Correlations } \\
\hline \multirow{3}{*}{ Spearman's rho } & \multirow{3}{*}{ Exposure } & Correlation Coefficient & Exposure & Systolic \\
\cline { 3 - 5 } & & Sig. (2-tailed) & 1.000 & .220 \\
\cline { 3 - 5 } & N &. & .067 \\
\cline { 3 - 5 } & \multirow{3}{*}{ Systolic } & Correlation Coefficient & .220 & 70 \\
\cline { 3 - 5 } & & Sig. (2-tailed) & .067 & .000 \\
\cline { 3 - 5 } & $\mathrm{N}$ & 70 & 70 \\
\hline
\end{tabular}

Table 4. Relationship between CO Exposure and Diastolic Blood Pressure

\begin{tabular}{|r|l|l|r|r|}
\hline \multicolumn{5}{|c|}{ Correlations } \\
\hline \multirow{3}{*}{ Spearman's rho } & \multirow{3}{*}{ Exposure } & Correlation Coefficient & Exposure & Diastolic \\
\cline { 3 - 5 } & & Sig. (2-tailed) & 1.000 & .063 \\
\cline { 3 - 5 } & $\mathrm{N}$ & .606 & .606 \\
\cline { 3 - 5 } & \multirow{3}{*}{ Diastolic } & Correlation Coefficient & .063 & 1.000 \\
\cline { 3 - 5 } & & Sig. (2-tailed) & .606 &. \\
\cline { 3 - 5 } & $\mathrm{N}$ & 70 & 70 \\
\hline
\end{tabular}

The results of the bivariate analysis between carbon monoxide exposure (intake) and systolic blood pressure showed that there was no significant relationship $(\mathrm{p}=0.067, \quad \mathrm{p}>0.05)$. The correlation coefficient obtained is 0.220 , this indicates a very weak relationship between exposure to carbon monoxide and systolic pressure. The correlation coefficient shows a positive number, which means that carbon monoxide exposure and systolic pressure has a unidirectional relationship, meaning that if carbon monoxide exposure increases, the systolic pressure will also increase.

The same results were also shown by the results of the bivariate analysis between carbon monoxide exposure (intake) and diastolic blood pressure, which was not a significant relationship ( $\mathrm{p}=0.606, \mathrm{p}>0.05)$. The correlation coefficient shows the number 0.063 which is positive, meaning that the relationship between the two is unidirectional. If the exposure to carbon monoxide increases, the diastolic pressure will also increase. The strength of the association between $\mathrm{CO}$ exposure and diastolic blood pressure is very weak.

Can be summarized, The results showed that 54.3 percent of mechanics had high blood pressure and there was one workshop that had a $\mathrm{CO}$ concentration in the air that exceeded the quality standard value, namely $31,329.2 \mu \mathrm{g} / \mathrm{Nm} 3$. There was a significant relationship between a history of hypertension $(\mathrm{p}=0.005)$, smoking habits $(\mathrm{p}=0.001)$, physical activity $(\mathrm{p}=0.006)$, and sodium intake $(\mathrm{p}=0.015)$ with blood pressure. There was no significant relationship between exposure of carbon monoxide and systolic pressure $(\mathrm{p}=0.067)$ and diastolic $(\mathrm{p}=0.606)$.

\section{CONCLUSION AND SUGGESTION}

The results showed that 54.3 percent of mechanics had high blood pressure and there was one workshop that had a $\mathrm{CO}$ concentration in the air that exceeded the quality standard value, namely $31,329.2$ $\mu \mathrm{g} / \mathrm{Nm} 3$. There was a significant relationship between a history of hypertension $(\mathrm{p}=0.005)$, smoking habits $(\mathrm{p}=0.001)$, physical activity $(\mathrm{p}=0.006)$, and sodium intake $(\mathrm{p}=0.015)$ with blood pressure. There was no significant relationship between exposure of carbon monoxide and systolic pressure $(\mathrm{p}=0.067)$ and diastolic $(\mathrm{p}=0.606)$.

Mechanics should be able to change and control risky lifestyles by increasing physical activity, controlling cigarette consumption, reducing sodium consumption, routinely going to health 
Kanaya Yori Damanik et.al. Relationship of characteristics, lifestyle and exposure of carbon monoxide with blood pressure of motorcycle repair shop mechanics at Medan City in 2020.

services and taking hypertension drugs for mechanics who have high blood pressure.

\section{REFERENCES}

1. Dinas Kesehatan Provinsi Sumatera Utara. (2015). Profil Kesehatan Provinsi Sumatera Utara Tahun 2015.

2. Guyton, A.C \& Hall, J.E. (2016). Fisiologi Kedokteran. Philadelphia: Elsevier.

3. Kementerian Kesehatan. (2014). Hipertensi. Infodatin Pusat Data dan Informasi Kementerian Kesehatan.

4. Kemenkers RI. (2018). Laporan Hasil Riset Kesehatan Dasar (Riskesdas) Nasional 2018. Jakarta: Balitbang Kemenkes RI.

5. Kemenkes RI. (2019). Know Your Number, Kendalikan Tekanan Darahmu dengan Cerdik. Jakarta: P2PTM Kemenkes RI.

6. Nuranto. (2014). Pengaruh Tingkat Kecemasan Terhadap Tekanan Darah Pada Pasien Hipertensi di Puskesmas Kedungmundu Semarang. Semarang:
Fakultas Ilmu Keperawatan dan Kesehatan Universitas Muhammadiyah Semarang.

7. Sarudji. (2010). Kesehatan Lingkungan. Bandung: Karya Putra Darwati.

8. Sarumaha, E.K. Diana, V.F. (2018). Faktor Risiko Kejadian Hipertensi pada Usia Dewasa Muda di UPTD Puskesmas Perawatan Plus Teluk Dalam Kabupaten Nias Selatan. Jurnal Kesehatan Global, 1(2).

9. Soedarmo, H. (2008). Panduan Praktis Merawat dan Memperbaiki Sepeda Motor. Jakarta: Gramedia.

10. Watson, R. (2002). Anatomi dan Fisiologi untuk Perawat. Jakarta: Penerbit EGC.

How to cite this article: Damanik KY, Nurmaini, Marsaulina I. Relationship of characteristics, lifestyle and exposure of carbon monoxide with blood pressure of motorcycle repair shop mechanics at Medan City in 2020. International Journal of Research and Review. 2021; 8(2): 61-67. 